\title{
Adolescent depression in schools: + Contigo Project
}

\author{
Depressão em adolescentes em meio escolar: Projeto + Contigo \\ Depresión en adolescentes en las escuelas: Proyecto + Contigo
}

Maria Pedro Queiroz de Azevedo Erse*; Rosa Maria Pereira Simões**; Jorge Daniel Neto Façanha***; Lúcia

Amélia Fernandes Alves Marques ${ }^{* * * *}$; Cândida Rosalinda Exposto Costa Loureiro*****; Maria Ermelinda Teixeira Sampaio Matos ${ }^{* * * * * *}$; José Carlos Pereira Santos*******

\begin{abstract}
Background: Adolescent depression is considered a public health issue in Portugal, despite the lack of national epidemiological data. It involves a high degree of mortality, namely by suicide, which is the third leading cause of death in the 15-24 age group.

Objectives: To assess the presence and severity of depressive symptoms in a non-clinical population of adolescents.

Methodology: This is a quantitative, descriptive and cross-sectional study, using the Portuguese version of the Beck Depression Inventory (BDI-II). The sample was composed of 741 adolescents.

Results: The results show that $31.2 \%$ of the adolescents have depression and, of these, $17.7 \%$ have moderate to severe depressive symptoms. Girls have higher levels of depression $(p=.00)$. The total mean score in the BDI-II was 12.

Conclusion: Given the adolescents' high vulnerability to depression and suicide, it is essential to implement prevention programs in schools to promote the early detection of depression and suicidal behaviors, and the referral to mental health services.
\end{abstract}

Keywords: adolescents; depression; suicide; prevention

\section{Resumo}

Enquadramento: A depressão nos adolescentes é considerada um problema de saúde pública em Portugal, embora não existam dados epidemiológicos nacionais. Envolve um elevado grau de mortalidade, principalmente por suicídio. O suicídio corresponde à $3{ }^{\text {a }}$ causa de morte entre os 15 e os 24 anos.

Objetivos: Avaliar a presença e severidade de sintomas depressivos numa população não clínica de adolescentes.

Metodologia: É um estudo descritivo e transversal, de natureza quantitativa utilizando a versão portuguesa do Inventário de Depressão de Beck (BDI-II). A amostra foi constituída por 741 adolescentes.

Resultados: Apresentam depressão 31,2\% dos adolescentes e destes $17,7 \%$ apresentam sintomatologia depressiva moderada a grave. As raparigas evidenciam níveis de depressão mais elevados $(p=0,00)$. A média das pontuações totais no BDI-II foi de 12 .

Conclusão: Atendendo à elevada vulnerabilidade dos adolescentes para a depressão e suicídio, é essencial a implementação de programas de prevenção em meio escolar que promovam a deteção precoce da depressão e de comportamentos suicidários e a referenciação para os serviços de saúde mental.

Palavras-chave: adolescentes; depressão; suicídio; prevenção

\footnotetext{
* RN, Specialist Nurse, CHUC, EPE- Polo Sobral Cid, 3040-714 Castelo Viegas, Portugal [mariaerse80@ gmail. $\mathrm{com}$. Contribution to the article: data collection and writing of the article. Address for correspondence: Ru Dr. Pedro Lemos n $n^{0} 621^{\circ}$ Esq, $3200-237$ Lousã, Portugal.

*.* MSc., RN, Coimbra Hospital and University Center, 3000-075 Coimbra, Portugal [rosasimoes18@gmail. $\mathrm{com}]$. Contribution to the article: data collection and revision of article-

**** MSc., RN, Coimbra Hospital and University Center, 3000-075 Coimbra Portugal [jorgefacanha@gmail. $\mathrm{com}$. Contribution to the article: data collection and revision of article

***** MSc., Specialist Nurse, Community Nursing, Department of Public Health, Regional Health Administration of the Center, 3000-011 Coimbra Portugal [lucia.amelia.marques@gmail.com]. Contribution to the article: data collection and revision of article-

******* Ph.D., Adjunct Professor, Nursing School of Coimbra, 3046-851, Coimbra, Portugal [candida@esenfc. pt]. Contribution to the article: data collection and revision of article

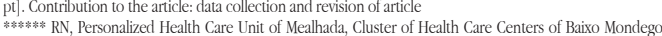
3050-000 Mealhada, Portugal [ermelindamatos64@ $@$ hotmail.com]. Contribution to the article: data collection

and revision of article
$* * * * * * * *$ Ph.D., Coordinating Professor, Nursing School of Coimbra, 3046-851, Coimbra, Portugal [jcsantos@ esenfc.pt]. Contribution to the article: data collection and revision of article
}

\section{Resumen}

Marco contextual: La depresión en los adolescentes se considera un problema de salud pública. En Portugal no hay datos epidemiológicos nacionales para la depresión en adolescentes. Este problema conlleva un grado elevado de mortalidad, principalmente por suicidio. El suicidio es la tercera causa de muerte entre los 15 y los 24 años.

Objetivos: Evaluar la presencia y la severidad de los síntomas depresivos en una población no clínica de adolescentes.

Metodología: Se trata de un estudio descriptivo y transversal, cuantitativo, para el cual se utilizó la versión portuguesa del Inventario de Depresión de Beck (BDI-II). La muestra estuvo formada por 741 adolescentes con una edad media de 13,85 años.

Resultados: El 31,2\% de los adolescentes sufre depresión y, de estos, el 17,7\% tiene síntomas depresivos moderados o severos. Las chicas muestran niveles más elevados de depresión $(p=0,00)$. La media de las puntuaciones totales en el BDI-II fue de 12.

Conclusión: Dada la elevada vulnerabilidad de los adolescentes a la depresión y al suicidio, es esencial poner en práctica programas de prevención en las escuelas que promuevan la detección precoz de la depresión y de los comportamientos suicidas, así como la derivación a los servicios de salud mental.

Palabras clave: adolescentes; depresión; suicidio; prevención

Received for publication: 14.05 .15

Accepted for publication: 06.04 .16 


\section{Introduction}

Suicide is one of the five leading causes of death worldwide in the 15-19 age group, and the third leading cause of death in the 15-24 age group (Callahan, Liu, Purcell, Parker, \& Hetrick, 2012; World Health Organization [WHO], 2014). For this reason, suicide in adolescents is a public and mental health concern, with a significant socio-economic and family impact (Santos, Erse, Façanha, Marques, \& Simões, 2014).

Suicide in Portugal continues to be a phenomenon which affects mainly older people. However, in addition to the underreporting of suicide cases, we are currently witnessing an increase in the number of years of potential life lost, which may indicate an increase of suicides among increasingly younger people (Direção Geral de Saúde [DGS], 2013). In 2012, the overall suicide rate in Portugal was $10.2 / 100,000$ inhabitants. In the 15-24 age group, the overall rate was $3 / 100,000$ inhabitants: 4.5 in boys and 1.4 in girls.

The entire spectrum of suicidal behavior includes suicidal acts (suicide and attempted suicide) and self-harm behaviors. With respect to suicidal acts, boys commit suicides more often, using more lethal methods, such as jumping and firearms. The most common methods used by girls are drug intoxication, especially with psychotropic drugs (Wilcox et al, 2010; DGS, 2013).

It is important to note that self-harm behaviors are the most common behaviors among adolescents and young adults and are characterized by self-mutilation or intoxication/overdose without suicidal intention (DGS, 2013; Wilcox et al., 2010). These behaviors simulate the far-distant desire to end life and are a way of expressing and coping with the deep psychological distress and pain; physical pain is seen by adolescents as a way to relieve the psychological pain and give them a sense of control over themselves (Reis, Figueira, Ramiro, \& Matos, 2012). Between 13\% and 25\% of the adolescents and young adults report having had at least one episode of self-directed violence throughout their lives, with a higher incidence among young girls (Wilcox et al., 2010).

In a study carried out in 2010, involving 5,050 Portuguese adolescents with a mean age of 14 years, Reis et al. (2012) reported that $15.6 \%$ of the adolescents had at least one of behavior of self-directed violence in the previous 12 months. The most common methods were self-mutilation and intake of sublethal doses of toxic products or medication.

Suicidal ideation and self-harm behaviors are important predictors for suicide attempt among adolescents and are therefore associated with suicide risk (Nock et al, 2013; Wilcox et al, 2010).

Many authors reinforce that suicidal behaviors in adolescence are often associated with high-risk psychiatric disorders. Around $90 \%$ of the young people who committed suicide were diagnosed with a mental disorder, and it is estimated that $60 \%$ suffered from depression (DGS, 2013).

The + Contigo Project is a longitudinal research project based on a multilevel network intervention aimed at promoting mental health and well-being and preventing suicidal behaviors. Within this scope, the study aims to assess the presence and severity of depressive symptoms in a non-clinical population of adolescents.

\section{Background}

Epidemiological data reveal prevalence rates of adolescent depression between 3\% to $9 \%$ and a cumulative prevalence of $20 \%$ until late adolescence, with a recurrence rate from $60 \%$ to $70 \%$ (Callahan et al., 2012). A discrepant predominance was found in women, with more prolonged episodes and greater risk of chronicity (Nock et al., 2013).

Depression in adolescence is a major cause of morbidity and mortality associated with difficulties in interpersonal relationships, deficits in academic performance, and with an increased risk for substance abuse, aggressive behavior, inappropriate sexual activity, and suicidal behavior (Brochado \& Brochado, 2008).

Several studies in adolescent populations call attention to the severity of the psychopathological depressive context associated with suicidal behavior (Callahan et al., 2012; Iosue et al., 2012), showing a strong correlation between depression, suicidal ideation, and suicidal behaviors.

Although it is common in this age group, depression is clearly underdiagnosed. On the other hand, there are some discrepancies in the existing data, which may be partly explained by different definitions and diagnostic methods (Balázs et al., 2013). However, using the 
same assessment instrument, the Beck Depression Inventory (BDI II), Table 1 shows that 9.2\% to 14\% of adolescents suffer from moderate and severe depression, with a higher prevalence among girls.

Table 1

Studies on the prevalence of depression in non-clinical populations of adolescents, using the BDI II

\begin{tabular}{|c|c|c|c|}
\hline Author of the study & Sample Size & Age (years) & Main results \\
\hline Coelho, Martins, and Barros (2002) & 775 & $15-19$ & Mean BDI II $=10.31$; Girls -11.48 ; Boys $-8.45^{*}$ \\
\hline $\begin{array}{l}\text { Osman, Barrios, Gitierrez, Williams, } \\
\text { and Balley (2008) }\end{array}$ & 414 & $14-18$ & Mean BDI II $=12.50$ \\
\hline Brochado and Brochado (2008) & 340 & $\begin{array}{c}13-16 \\
X=13.92\end{array}$ & $\begin{array}{l}\text { Mean BDI II }=11.4 \\
\text { Girls: } 13.43 \text {; Boys: } 10.92 * \\
\text { 14\% with moderate to severe depressive symptoms }\end{array}$ \\
\hline Paranhos (2009) & 391 & $X=15.12$ & $\begin{array}{l}\text { Mean BDI II }=10.38 \\
13.5 \% \text { with moderate to severe depressive symptoms }\end{array}$ \\
\hline Iosue et al. (2012) & 1195 & $X=15.3$ & $\begin{array}{l}\text { Mean BDI II }=8 \\
\text { Girls: } 8.83 ; \text { Boys: } 6.22 * \\
9.2 \% \text { with moderate to severe depressive symptoms }\end{array}$ \\
\hline
\end{tabular}

$* p<.001$

The diagnostic difficulties and delay in treatment initiation may be related to several causes: the stigma associated with mental disorders, the atypical presentation of symptoms, the lack of adequate training for health professionals, the disbelief in the success of treatments, and the obstacles in the access to mental health care (Wilcox et al., 2010).

Although it is consensual that depression in adolescents has specific manifestations in this age group, it is possible to find symptoms similar to depressive disorders in adults. Irritability, episodes of aggressiveness, consumption of alcohol and other types of substances, concentration difficulties, poor academic and social performance, low selfesteem, suicidal ideation, and suicidal behaviors are typical manifestations of depression in adolescents (Paranhos, 2009; Santos \& Neves, 2014).

Callahan et al. (2012) report that, especially among the adolescent population, depressive manifestations often assume the form of multiple physical complaints. It becomes essential to identify the somatic disorders so that the psychopathological disorder is not masked by subtle symptoms which may be difficult to recognize, such as migraines, muscle pain, palpitations and constipation. This trend toward the somatization of depressive symptoms seems to be associated with the inability to communicate emotions and negative thoughts.

In Portugal, the prevalence of depression in adults is $25.8 \%$ throughout the life cycle and $7.9 \%$ in the past 12 months (Caldas de Almeida \& Xavier, 2013). However, there are no national data for the prevalence of this mental disorder among adolescents.

As depressed adolescents are at greater risk for suicide, the triggering factors of suicidal behaviors must be clearly established and depression should be treated as early as possible. The purpose of the treatment is to manage depressive symptoms and improve the adolescents' intra- and interpersonal, academic, family and social functioning. The most promising treatments involve a combination of psychotherapeutics and psychotherapy, namely cognitive-behavioral therapy, interpersonal therapy and dialectical behavioral therapy (Ordem dos Enfermeiros, 2012; Reis et al., 2012).

International and national guidelines advocate that the most effective methods for preventing suicide result from a synergy between several strategies, such as the early detection and appropriate treatment of mental disorders, namely depression, the restriction of lethal means, the strengthening of protective factors, and the reduction of risk factors (DGS, 2013; Santos, Erse et al., 2014; WHO, 2014).

In Portugal, the National Plan of Suicide Prevention 2013/2017 (DGS, 2013) advocates the need for school-based prevention programs and puts forward priority activities to be developed with adolescents, pointing out strategies such as prevention campaigns in schools focused on reducing stigma, the early identification of depression and suicidal behaviors, and greater accessibility to health care services. 
Several authors argue that the school is a privileged place for a preventive intervention aimed at detecting mental disorders as early as possible and referring students to mental health services. Health professionals, namely primary health care professionals, and education agents are in a privileged position for signaling and referring adolescents and identify signs of depression and suicidal behaviors (Santos, Erse et al., 2014; Santos, Simões, Erse, Façanha, \& Marques, 2014).

In this context, the school is believed to be a center for mental health promotion due to the investment in strategies that support the development of personal and individual skills, positive attitudes toward oneself and the others, resilience and group cohesion, and that promote a healthy school environment, help-seeking behaviors, the reduction of stigma in mental health, and the prevention or early identification of mental disorders and suicidal behaviors (Simões, Erse, Façanha, \& Santos, 2014).

\section{Research question}

What is the incidence and severity of depression in adolescents attending the schools that integrate the + Contigo Project, in the academic year 2011/2012?

\section{Methodology}

The main objectives of the + Contigo Project, developed by the authors, are the promotion of mental health and well-being and the prevention of suicidal behaviors in 7 th- to 12th-graders attending education institutions in Portugal. It is sponsored by the Regional Health Administration of the Center Region, the Nursing School of Coimbra and the Health Sciences Research Unit: Nursing.

Given its conceptual model, the project is considered a multilevel program, since it promotes the increase of knowledge about suicide and of specific skills to identify and refer risk situations, involving the whole educational community (parents and tutors/ guardians, education agents and students) and health professionals of the reference area.

A specialized intervention is conducted with the adolescents throughout the academic year, using sociotherapeutical games which focus on mental health stigma, adolescence, physical and mental well-being, self-concept, depression and problem-solving strategies. The intervention is assessed in three specific moments: $1^{\text {st }}$ assessment (diagnostic evaluation - before the beginning of the intervention), $2^{\text {nd }}$ assessment (after the intervention), and $3^{\text {rd }}$ assessment (6 months after the intervention). This assessment is carried out through a questionnaire composed of several scales that allow assessing variables such as well-being, coping, self-concept, and depression (Santos, Erse et al., 2014).

With regard to the formal and ethical aspects, we asked the Services of Educational Projects of the Directorate-General for Education for permission to apply the + Contigo Questionnaire (Survey no. 0224900002), ensuring the participants' anonymity and confidentiality. The + Contigo Project is integrated in the Educational Plan of each School Cluster/School, after permission is granted by the parents and tutors/guardians for the application of the questionnaires.

Here, we will only discuss the data concerning the assessment of depression in the first phase of the project, without any previous intervention.

Data were collected between the September and November of the academic year 2011/2012. Taking into account the health plan of each school, we selected a convenience sample composed of 741 students from 7 School Clusters (Mealhada, Tocha, Figueira da Foz, Estarreja, Ovar, Alhadas, Anadia), which were integrated in two clusters of health care centers (Mondego and Baixo Vouga). The questionnaires were completed anonymously in a classroom, under the supervision of the local liaison persons, and put into sealed envelopes.

The Beck Depression Inventory (BDI), developed by Beck, Steer, and Brown (1996), is one of the most commonly used self-administered instruments for the detection and measurement of the intensity of depressive symptoms.

This inventory was modified and a new version was created - the BDI-II, which is used in this study. It is composed of 21 items, each one with four statements/ possible responses, with the exception of items 16 and 18 which have seven statements. Respondents are asked to consider each statement as it relates to the way they have felt for the past 2 weeks, including that day. The partial scores per item range from 0 to 3 points. The total score corresponds to the intensity 
of depression severity, and results from the sum of the individual items. The possible maximum score is 63 points. Total scores from 0 to 13 correspond to minimal depression, from 14 to 19 to mild depression, from 20 to 28 to moderate depression, and $>29$ to severe depression (Beck et al., 1996).

The BDI-II is a tool widely used in clinical and non-clinical populations of adolescents (Table 1). Studies of the psychometric properties of the BDI-II within this age group include those by Beck et al. (1996), Coelho et al. (2002), Osman et al. (2008), and Iosue et al. (2012).

In addition to the interpretation of the total score obtained, Beck et al. (1996) attach particular importance to the content analysis of specific items. An analysis of the specific scoring items and the score given to each one can prevent more severe situations which cannot be seen in the total score. The authors suggest that special attention should be given to items that integrate the diagnosis of depression and that assess suicidal ideation and pessimism, predicting a suicidal behavior. Thus, the situations combining items 2 (pessimism) and 9 (suicidal thoughts or desires) with scores above zero associated with any level of depression, mainly to moderate or severe depression, require a more detailed assessment and intervention with adolescents and their family, since they point to a risk of suicidal behavior (Beck et al., 1996; Paranhos, 2009).

The data obtained through the application of the data collection instrument were analyzed using the
Statistical Package for the Social Sciences (SPSS), version 19 for Windows XP.

\section{Results}

The sample was composed of 741 adolescents, mainly boys $(53.17 \%)$, attending the $8^{\text {th }}$ grade $(60.7 \%)$ and with a mean age of 13.85 years.

Mealhada was the most representative School Cluster, with 215 students.

\section{Prevalence of depression}

The total mean score in the BDI-II of the study sample was 12, ranging between a minimum of 2 and maximum of 62 , with a standard deviation of 9.55 . In this sample, $31.2 \%$ of the adolescents had depressive symptoms, $17.7 \%$ of whom had moderate to severe depression.

Girls had higher total mean scores $(X=13.48)$ than boys $(X=10.70)$, this being a statistically significant difference $(t=-3.97 ; p=.00)$.

Table 2 shows that $14.47 \%$ of the boys $(n=57)$ and $21.3 \%$ of the girls $(n=74)$ had moderate to severe depressive symptoms. It also shows that, of the 131 adolescents with moderate to severe depression, 82.4\% were aged between 13 and 15 years and that, although not statistically significant, the incidence is higher among girls.

Table 2

Distribution of the sample with depressive symptoms by gender and age

\begin{tabular}{|c|c|c|c|c|c|c|c|c|c|}
\hline \multirow{2}{*}{$\begin{array}{c}\text { DEPRESSION AND } \\
\text { GENDER }\end{array}$} & \multicolumn{8}{|c|}{ AGE } & \multirow{2}{*}{ TOTAL (\%) } \\
\hline & 11 & 12 & 13 & 14 & 15 & 16 & 17 & 18 & \\
\hline \multicolumn{10}{|l|}{ Male } \\
\hline Minimal to mild & 2 & 20 & 152 & 104 & 45 & 13 & 1 & 0 & 337 (85.53\%) \\
\hline Moderate to severe & 0 & 3 & 18 & 18 & 7 & 8 & 1 & 2 & $57(14.46 \%)$ \\
\hline \multicolumn{10}{|l|}{ Female } \\
\hline Minimal to mild & 0 & 13 & 140 & 84 & 22 & 9 & 3 & 2 & $273(78.67 \%)$ \\
\hline Moderate to severe & 0 & 7 & 22 & 27 & 16 & 2 & 0 & 0 & $74(21.33 \%)$ \\
\hline
\end{tabular}

In order to identify the group of students at higher risk for suicidal behaviors from the sample, we found that 69 of the 741 students are at greater risk for adopting a suicidal behavior, which is equivalent to 9.3\% of the sample. Furthermore, among these 69 adolescents, we found a predominance of girls (41) aged between 13 and 15 years.

\section{Discussion}

In the study sample, the total mean score obtained was 12 , which indicates that the overall sample has minimal depressive symptoms (Beck et al., 1996). If we take the cut-off point suggested by Coelho et al. 
(2002) as reference, we conclude that, in general, the sampled adolescents are not depressed (total scores BDI II $\leq 13$ - no depressive symptoms).

Taking into account the studies mentioned in Table 1, we found similar results in the studies of Coelho et al. (2002), Brochado and Brochado (2008), and Osman et al. (2008). However, the mean ages in these studies are higher than those in our study. In the studies of Paranhos (2009) and Iosue et al. (2012), the mean scores of the BDI-II are markedly lower than those obtained in our study.

With regard to the total scores of the BDI-II, we found that $68.8 \%$ of the adolescents have minimal depression, $13.5 \%$ have mild depression, $11.3 \%$ have moderate depression, and 6.4\% have severe depression. Similar results were found in the study of Brochado and Brochado (2008).

We found significant differences when analyzing the adolescents with total scores corresponding to moderate to severe depression. In this study, $17.7 \%$ of the sample subjects scored moderate to severe depression (BDI II $\geq 20$; Beck et al., 1996). The same level of depression was found in other studies, although with different percentages: $14 \%$ in Brochado and Brochado (2008), 13.5\% in Paranhos (2009) and 9.2\% in Iosue et al. (2012). The study on the prevalence of depression in Europe (Saving and empowering young lives in Europe - SEYLE), which involved 12,395 adolescents from 11 countries, with a mean age of 14.81 , found very different levels of moderate to severe depression, for example in Hungary (7.1\%), Spain (8.6\%), Germany (12.9\%), France (15.4\%), and Israel (19.4\%; Iosue et al., 2012). In view of the above, we can argue that there are clear differences in the prevalence of depression in these studies. These differences can be related, among other factors, to the adolescents' different cultural, social, economic and religious contexts. The high values found in Portugal are undoubtly related to the emerging socioeconomic crisis at the time of data collection.

In this study, the girls obtained higher total mean scores (13.48) than the boys (10.70), which is a statistically significant difference. Similar results, although lower, were found in most of the studies (Brochado \& Brochado, 2008; Coelho et al., 2002; Isoue et al, 2012).

In our sample, there is a higher prevalence of depressive symptoms among girls, as can be seen in Table 2. These data are corroborated by several authors (Coelho et al., 2002; WHO, 2014). We also found that the incidence of moderate to severe depressive symptoms is more predominant in girls (21.3\%) than in boys (14.47\%). These results, for both girls and boys, are higher than those found by Brochado and Brochado (2008).

The risk of depression in adolescence is higher among girls, which can be explained by biopsychosocial and cultural factors, a premature social life, family conflicts, individual autonomy, among others. Nolen-Hoeksema and Girgus (1994) justify this higher risk for depression based on the high number of biological and social risk factors that are associated with girls and that increase during adolescence due to the need to overcome the several challenges and fulfill developmental tasks.

The results in Table 2 regarding the age variable reveal that there is a significant increase in the prevalence of depressive symptoms between the age of 13 and 15 , although no statistically significant correlation has been found.

Of the adolescents with moderate to severe depressive symptoms, $82.4 \%$ (65 girls and 43 boys) are aged between 13 and 15 years. In girls, the level of depressive symptoms is higher at 14 years of age, which is a similar result to that found in the study of Brochado and Brochado (2008). Nolen-Hoeksema and Girgus (1994) mention that, around the age of 13/14, girls have higher levels of depression than boys, explaining these findings with the strong increase of physical, social and emotional challenges, the different styles of coping and the hormonal changes. The coping strategies used by girls to solve problems or stressful situations tend to be less aggressive and more rumination-focused (Nolen-Hoeksema \& Girgus, 1994), which seems to make them more vulnerable to depression.

In order to identify the group of students at higher risk for suicidal behaviors among the 741 sampled students, we found that 69 adolescents are at higher risk for adopting a suicidal behavior, which corresponds to $9.3 \%$ of the sample. Furthermore, out of the 69 adolescents, there is a predominance of the female gender (41) and of the 13-15 age group. These data justify the need for designing strategies that take into account the specificity of this group, since girls seem to be more vulnerable to depression and, consequently, at higher risk for suicidal behaviors. 
As limitations of this study we highlight the fact that it is a cross-sectional study, which limited the information produced. Longitudinal studies can help us to better understand the evolution of the mental health status. However, despite being limited by its cross-sectional design that prevented us to identify the predictive variables for depression in adolescence, the obtained data confirm the importance of this study.

Another limitation is the fact that we only analyzed self-reported data, which makes us consider the possible influence of social desirability in the answers given by the adolescents.

\section{Conclusion}

In order to meet the purpose of the study, we found that the total mean score in the BDI-II of the study sample was 12. Girls had higher total mean scores $(p=.00)$. In this sample, $31.2 \%$ of the adolescents had depressive symptoms, of whom $17.7 \%$ had moderate to severe depressive symptoms, with a higher incidence among girls and within the 13-15 age group. The high prevalence of depression found, the severe impact on the adolescent's physical and mental well-being, and the strong association between depression and suicidal behaviors require a strategy for the early detection and an adequate treatment and follow-up. As a key place for mental health promotion, the school should be considered as a privileged place to invest not only in prevention, but also in the intervention and referral to mental health care. Therefore, programs should be developed to prevent depression and suicidal behaviors in schools that contribute to assessing the presence and severity of depression and implementing preventive strategies with a view to increasing individual and personal skills, self-esteem, problem-solving skills and help-seeking behaviors, thus reducing the risk factors and increasing the protective factors.

This study highlights the importance of increasing the number of mental health professionals in schools, investing in the health professionals' training and practice, and increasing mental health literacy in the educational community (teachers, parents/guardians and students) so as to empower them to identify the signs and symptoms of depression and the risk factors associated with suicidal behaviors, and to provide an informed, appropriate and timely response.
Other aspects that should be covered in both the preventive and treatment and intervention strategies aimed at depressed adolescents include working with the families and strengthening the support networks, since effective family relationships and healthy friendships are essential resources for adolescents and have proven to be highly important protective factors against depression and suicidal behaviors.

Further studies should use a larger sample so as to contribute to an epidemiological characterization of mental disorders among Portuguese adolescents.

\section{References}

Balázs, J., Miklósi, M., Keresztény, A., Hoven, C. W., Carli, V., Wasserman, C., ... Wasserman D. (2013). Adolescent subthreshold-depression and anxiety: Psychopathology, functional impairment and increased suicide risk. Journal of Child Psychology and Psychiatry and Allied Disciplines, 54(6), 670-677. doi: 10.1111/jcpp.12016

Beck, A., Steer, R., \& Brown, G. (1996). Manual for Beck Depression Inventory II. San Antonio, USA: TX Psychological Corporation.

Brochado, F., \& Brochado, A. (2008). Estudo da presença de sintomatologia depressiva na adolescência. Revista Portuguesa de Saúde Pública, 26(2), 27-36. Retrieved from https://www.ensp.unl.pt/dispositivos-de-apoio/cdi/ cdi/sector-de-publicacoes/revista/2000-2008/pdfs/rpsp-22008/03.pdf

Caldas de Almeida, J., \& Xavier, M. (2013). Estudo epidemiológico nacional de saúde mental (vol. 1). Lisboa, Portugal. Faculdade de Ciências Médicas, da Universidade Nova de Lisboa.

Callahan, P., Liu, P., Purcell, R., Parker, A., \& Hetrick, S. (2012). Evidence map of prevention and treatment interventions for depression in young people. Depression Research and Treatment, 2012(820735), 1-11. doi:10.1155/2012/820735

Coelho, R., Martins, A., \& Barros, H. (2002). Clinical profiles relating gender and depressive symptoms among adolescents ascertained by the Beck Depression Inventory II. European Psychiatry, 17(4), 222-226. doi:10.1016/S09249338(02)00663-6

Direção Geral de Saúde. (2013). Plano nacional de prevenção do suicídio 2013/2017. Lisboa, Portugal: Autor.

Iosue, M., Carli, V., D `Aulerio, M., Basilico, F., Di Domenico, A., Recchia, L., ... Wasserman, D. (2012). Depression and suicidal ideation among Italian adolescents: Preliminary results from the SEYLE project. European Psychiatry, 27 (sup. 1). doi:10.1016/S0924-9338(12)75593-1

Nock, M., Green, J., Hwang, I., McLaughlin, K., Sampson, B., \& Zaslavsky, A. (2013). Prevalence, correlates, and 
treatment of lifetime suicidal behavior among adolescents: Results from the National Comorbidity Survey Replication Adolescent Supplement. Journal of the American Medical Association Psychiatry, 70(3), 300-310. doi:10.1001/2013. jamapsychiatry. 55

Nolen-Hoeksema, S., \& Girgus, J. (1994). The emergence of gender differences in depression during adolescence. Psychological Bulletin, 115(3), 424-443. doi: 10.1037/00332909.115.3.424

Ordem dos Enfermeiros (2012). Guia orientador de boas práticas para a prevenção de sintomatologia depressiva e comportamentos da esfera suicidária. Lisboa, Portugal

Osman, A., Barrios, F., Gutierrez, P., Williams, J., \& Bailey, J. (2008). Psychometric properties of the Beck Depression Inventory-II in nonclinical adolescent samples. Journal of Clinical Psychology, 64(1), 83-102. doi: 10.1002/jclp.20433

Paranhos, M. (2009). Estudo de fidedignidade e validade do inventário de depressão de Beck-II (BDI-II) em adolescentes (Master's dissertation). Universidade Católica do Rio Grande do Sul, Faculdade de Psicologia, Brasil.

Reis, M., Figueira, I., Ramiro, L., \& Matos, M. (2012). Jovens e comportamentos de violência autodirigida. In M. Matos \& G. Tomé (Eds.), Aventura social: Promoção de competências e do capital social para um empreendedorismo com saúde na escola e na comunidade: Estado da arte: Princípios, actores e contextos (vol.1, pp. 259-276). Lisboa, Portugal: Placebo.
Santos, J., Erse, M., Façanha, J., Marques, L., \& Simões, R. (2014). + Contigo: Promoção de saúde mental e prevenção de comportamentos suicidários na comunidade educativa. Revista de Enfermagem Referência, 3(10), 203-207. Retrieved from http://www.scielo.mec.pt/pdf/ref/ vserIIIn10/serIIIn10a22.pdf

Santos, J., Simões, R., Erse, M., Façanha, J., \& Marques, L. (2014). Impacto da formação "+ Contigo" nos conhecimentos e atitudes dos profissionais de saúde acerca do suicídio. Revista Latino-Americana, 22(4), 679-684. doi: 10.1590/01041169.3503 .2467

Santos, N., \& Neves, E. (2014). Adolescência e comportamentos suicidários. In C. Saraiva, B. Peixoto \& D. Sampaio (Coord.), Suicídio e comportamentos autolesivos: Dos conceitos à prática clínica (pp. 225-240). Lisboa, Portugal: Lidel.

Simões, R., Erse, M., Façanha, J., \& Santos, J. (2014). Enfermagem em suicidologia. In C. Saraiva, B. Peixoto \& D. Sampaio (Coord.), Suicídio e Comportamentos Autolesivos: Dos conceitos à prática clínica (pp. 193-202). Lisboa, Portugal: Lidel.

Wilcox, H., Arriab, A., Caldeira, K., Vincent, K., Pinchevskyc, G., \& O'Grady, K. (2010). Prevalence and predictors of persistent suicide ideation, plans, and attempts during college. Journal of Affective Disorders, 127(1-3), 287-294. doi: 10.1016/j. jad.2010.04.017

World Health Organization. (2014). Preventing suicide: A global imperative. Retrieved from http://www.who.int/mental_ health/suicide-prevention/world_report_2014/en/ 

